\title{
A SIMPLE TECHNIQUE FOR PREDICTING THE BIOMASS OF A PROSOBRANCH SNAIL*
}

\author{
Pinllum B. Davis† AND Homer K. Fenner \\ Department of Biology, University of Michigan-Flint, Flint, MI 48503, U.S.A.
}

(Received 22 December 1975)

\begin{abstract}
A simple technique was developed for accurately predicting the biomass of the freshwater prosobranch Viviparus contectuides (Mesogastrapoda: Viviparidae) (Binney, 1865).

2. Regression of dry weight (biomass) on wet weight yielded a regression coefficient $\left(\mathrm{r}^{2}\right)$ of 0.99 with an associated $P<0.001$.

3. Biomass, therefore, can be predicted by measuring wet weights without sacrificing specimens.
\end{abstract}

\section{INTRODUCTION}

The objective of this study was to develop an accurate method for prediciting the biomass of live specimens of Viviparus contectoides. The method was developed so that further research related to biomass could be performed with live specimens.

\section{MATERIALS AND METHODS}

The 36 snails utilized in this study were collected in October of 1973 from a small freshwater stream in Livingston County, MI. Sex was determined and wet and dry weight was measured. Observations of the presence or absence of a penis indicated there were 19 females and 17 males. Superficial moisture was removed from the live snails utilizing absorbent paper towcling. Each snail was subsequently weighted to the nearest $0.01 \mathrm{~g}$ on a Mettler balance to determine wet weight. Dry weights were determined by placing each snail in a tared aluminum cup and drying in an oven at $60^{\circ} \mathrm{C}$ until constant weight was achieved. Dry weight as determined by this procedure is considered synonymous with biomass.

\section{RESULTS}

Three regression analyses were performed to determine the relationship between dry weight $(Y)$ and wet weight $(X)$ for the sexes separately and combined (Table 1). There were no significant differences between the coefficients of regression for the three

* Reprint requests should be addressed to Dr. Gary L. Pace, Department of Biology, University of MichiganFlint, Flint, MI 48503, U.S.A.

$\uparrow$ Present address: Department of Fisheries and Wildlife, Michigan State University, East Lansing, MI 48824, U.S.A. analyses. Ranges of wet weights for females and males were $0.55-8.82 \mathrm{~g}$ and $0.30-2.64 \mathrm{~g}$, respectively. Although the ranges of weights for females and males differed, the intensity of the relationship between biomass and wet weight for both sexes combined was unusually high (Fig. 1). This was indicaed by the correlation coefficient $\left(r_{1}\right)$ and its associated probability level (Table 1).

\section{DISCUSSION}

It is now possible to accurately predict the biomass of Viviparus contectoides without sacrificing speci-

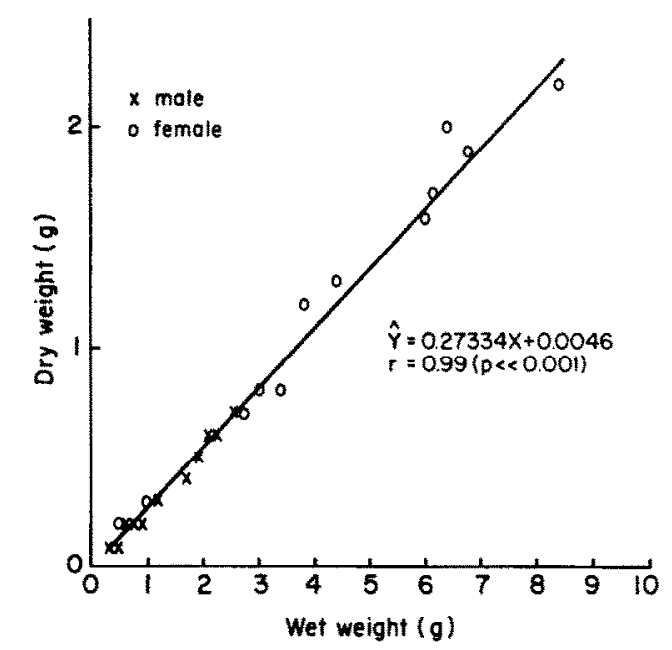

Fig. 1. Relationship between wet weight and dry weight (biomass) for 36 prosobranch snails (Vivipartus

Table 1. Relationships between wet weight (wt) and dry weight for 36 freshwater snails (Viviparus contectoides)

\begin{tabular}{|c|c|c|c|c|}
\hline \multirow[b]{2}{*}{$\begin{array}{l}\text { Dependent } \\
\text { (Y) }\end{array}$} & \multicolumn{4}{|l|}{ Variates } \\
\hline & $\begin{array}{c}\text { Independent } \\
(\mathrm{X})\end{array}$ & Regression equation & $\begin{array}{c}\mathrm{T} \text { of } \\
\mathrm{X} \& \mathrm{Y}\end{array}$ & $\begin{array}{l}r^{2} \text { of } \\
X \& Y\end{array}$ \\
\hline $\begin{array}{l}\text { Dry wt } q \& \sigma^{*} \\
\text { Dry wt }+ \\
\text { Dry wt } \delta^{*}\end{array}$ & $\begin{array}{l}\text { Wet wt } 9 \& \delta \\
\text { Wet wt } q \\
\text { Wet wt } \sigma^{*}\end{array}$ & $\begin{array}{l}\hat{\mathrm{Y}}=0.2733 \mathrm{X}(0.0051 \text { S.E. })+0.0046(0.0158 \text { S.E. }) \\
\hat{\mathrm{Y}}=0.2724 \mathrm{X}(0.0080 \text { S.E. })+0.0153(0.0326 \text { S.E. }) \\
\hat{\mathrm{Y}}=0.2526 \mathrm{X}(0.0069 \text { S.E. })+0.0201(0.0095 \text { S.E. })\end{array}$ & $\begin{array}{l}r_{1}=0.99+ \\
r_{2}=0.99+ \\
r_{3}=0.99+\end{array}$ & $\begin{array}{l}r_{1}^{2}=0.99 \\
r_{2}^{2}=0.98 \\
r_{3}^{2}=0.99\end{array}$ \\
\hline
\end{tabular}

$\ddagger$ Very highly significant $(P<0.001)$. 
mens. The biomass can be predicted from measurements of wet weight utilizing the regression equation $\hat{\mathrm{Y}}=0.2733 \mathrm{X}(0.0051$ S.E. $)+0.0046(0.0158$ S.E. $)$. A similar relationship of biomass to wet weight may exist in other species of mollusks, particularly other prosobranchs. Such an established relationship would allow physiological studies related to the biomass of known individuals over time (Fitch, 1975).

Acknowledgements-We thank Dr. Richard W. Dapson, Dr. Gary L. Pace and Dr. Eugene H. Studier of the Department of Biology at the University of Michigan-
Flint, and Mr. Thomas P. Husband of the Department of Fisheries and Wildlife, Michigan State University for their criticism, advice and encouragement throughout the study.

\section{REFERENCES}

BINNEY W. G. (1865) Land and frcsh-water shells of North America. Smithsonian misc. collections No. 144, part B, $16-115$.

Fitch D. D. (1975) Oxygen consumption in the prosobranch snail Viviparus contectoides (Mollusca: Gastropoda)-I. Effects of weight and activity. Comp. Biochem. Physiol. 51A, 815-820. 